\title{
Dengue: factors driving the emerging epidemic
}

This article was published in the following Dove Press journal:

Clinical Epidemiology

18 November 2013

Number of times this article has been viewed

\section{Muayad Ali}

Manufacturing Department, Australian Red Cross Blood Service, Dandenong, VIC, Australia
Correspondence: Muayad Ali Australian Red Cross Blood Service, New Street, Dandenong, VIC 3I7, Australia Email mali2I@student.monash.edu.au

\section{Dear editor}

I have read with great interest the article "Epidemiology of dengue: past, present and future prospects" by Murray et al. ${ }^{1}$ Dengue viruses are usually transmitted by Aedes mosquitoes, which are highly sensitive to environmental conditions. Temperature, rainfall, and humidity are critical to mosquito survival and reproduction; the higher temperatures minimize the required time for virus replication and dissemination in the mosquito. ${ }^{2}$ I accept that dengue will increase in the future as the article outlines, as climate change will contribute to a substantial increase in the number of people, and the proportion of the global population at risk of dengue fever. ${ }^{3}$

Despite the impact of climate change, I strongly believe more factors have contributed to the increase of dengue disease: social and environmental factors; the increase of urbanization; the lack of and/or poor health services; and the expansion of international travel and trade are all linked to the increase of dengue fever. ${ }^{4}$ There is still uncertainty regarding the impact of climate change on dengue vectors' expansion. I agree with the idea that human adaptation to environmental factors, such as drought, through the instillation of water storage tanks, may significantly contribute to the expansion of the disease, other than climate change factors. ${ }^{5}$

The World Health Organization (WHO) described dengue as a "neglected" tropical disease in its Dengue Prevention and Control Strategy 2012-2020, due to the lack of global coordination efforts, researches and political will. ${ }^{6}$ From my point of view, I consider that "neglect" is a reason the disease expanded to new regions, infecting new populations, and exposing more people to the risk of infection.

In conclusion, this letter addresses the impact of climate change on dengue disease and discusses other contributing factors that influence the vulnerability of populations to the health impact of climate change.

I agree that the expansion of dengue is multifactorial; climate change is one of the factors, but not the dominant one, since other factors may variously contribute, depending on the situation, and where and how the disease exists. The major factors may include: the unprecedented population growth associated with the urbanization increase in tropical, developing countries; substandard housing; overcrowding; and water and sewer quality.

\section{Disclosure}

The author reports no conflicts of interest in this communication. 


\section{References}

1. Murray NE, Quam MB, Wilder-Smith A. Epidemiology of dengue: past, present and future prospects. Clin Epidemiol. 2013;5:299-309.

2. Centers for Disease Control and Prevention. [homepage on the Internet]. Atlanta: Centers for Disease Control and Prevention; 2012 [updated September 27, 2012; cited June 9, 2010]. Available from: http://www.cdc. gov/dengue/entomologyEcology/climate.html. Accessed September 22, 2013.

3. Hales S, de Wet N, Maindonald J, Woodward A. Potential effect of population and climate changes on global distribution of dengue fever: an empirical model. Lancet. 2002;360(9336):830-834.

4. Health and Environment Linkages Initiatives. Better environmental management for control of dengue [webpage on the Internet]. Geneva: World Health Organization; 2013. Available from: http:/www.who.int/ heli/risks/vectors/denguecontrol/en/. Accessed October 10, 2013.
5. Beebe NW, Cooper RD, Mottram P, Sweeney AW. Australia's dengue risk driven by human adaptation to climate change. PLoS Negl Trop Dis. 2009;3(5):e429.

6. World Health Organization. Global Strategy for Dengue Prevention and Control 2012-2020. Geneva: World Health Organization; 2012. Available from: http://apps.who.int/iris/bitstream/10665/75303/1/9789 241504034_eng.pdf. Accessed October 10, 2013.

7. Gubler DJ. Dengue and dengue hemorrhagic fever. Clin Microbiol Rev. 1998;11(3):480-496. 


\section{Authors' reply}

\section{Mikkel B Quam \\ Natasha Evelyn Anne Murray ${ }^{1,2}$ \\ Annelies Wilder-Smith ${ }^{1,3}$}

'Institute of Public Health, University of Heidelberg, Heidelberg, Germany; ${ }^{2}$ Population Health, Waikato District Health Board, Hamilton, New Zealand; ' ${ }^{3}$ ee Kong Chian School of Medicine, Nanyang Technological University, Singapore

Correspondence: Annelies Wilder-Smith

Institute of Public Health, Im Neuenheimer Feld 365,

University of Heidelberg, 69120 Heidelberg, Germany

Tel +49622I564864

Email anneliesws@gmail.com

\section{Dear editor}

We appreciate the interest and response generated by our recently published article, "Epidemiology of dengue: past, present and future prospects". ${ }^{1}$

We agree with the author of the correspondence that the reasons for the recent decades' global expansion of dengue are multifactorial. As our review article summarizes, dengue expansion in the past decades has been driven by many factors, of which climate is only one. ${ }^{1}$ Human population dynamics such as urbanization, changing patterns of settlement, population growth, international travel, migration, and commercial trade, combined with anthropogenic changes in ecological habitats and neglected vector control, have all contributed to the increased dengue incidence and geographic expansion. ${ }^{1}$ The increase in dengue over the last half century is thus a result of the combination of factors that all constitute a matrix of broader "global change"., Of all the factors mentioned, our personal opinion is that the rapidly increasing global connectivity through travel is one of the main factors for dengue emergence into currently uninfected areas, ${ }^{3-6}$ and that uncontrolled urbanization is the main factor for the exponential increase of dengue cases in endemic countries. ${ }^{5,7}$
Climate change, including human adaptation to climate change, may have an increasing impact on the temperaturedependent survival range and seasonality of dengue vector mosquitoes, including the availability of breeding sites, both natural and artificial. ${ }^{8}$ In this manner, dengue vector expansion may indirectly be a result of climate change having altered patterns and behaviors of human settlement. ${ }^{1}$ Climate-related factors such as rainfall, humidity, and temperature have been shown to correspond with mosquito vector and dengue activity; ${ }^{9}$ however, the degree to which climate change is a primary factor driving the growth in dengue incidence remains uncertain and presents an area of ongoing research. ${ }^{10}$

\section{Disclosure}

The authors report no conflicts of interest in this communication.

\section{References}

1. Murray NE, Quam MB, Wilder-Smith A. Epidemiology of dengue: past, present and future prospects. Clin Epidemiol. 2013;5:299-309.

2. Reiter $\mathrm{P}$, Lathrop $\mathrm{S}$, Bunning $\mathrm{M}$, et al. Texas lifestyle limits transmission of dengue virus. Emerg Infect Dis. 2003;9(1):86-89.

3. Schwartz E, Meltzer E, Mendelson M, et al. Detection on four continents of dengue fever cases related to an ongoing outbreak in Luanda, Angola, March to May 2013. Euro Surveill. 2013;18(21)pii 20488.

4. Sessions OM, Khan K, Hou Y, et al. Exploring the origin and potential for spread of the 2013 dengue outbreak in Luanda, Angola. Glob Health Action. 2013;6:21822.

5. Wilder-Smith A, Gubler DJ. Geographic expansion of dengue: the impact of international travel. Med Clin North Am. 2008;92(6):1377-1390.

6. Wilder-Smith A, Schwartz E. Dengue in travelers. $N$ Engl J Med. 2005;353(9):924-932.

7. Wilder-Smith A, Ooi EE, Vasudevan SG, Gubler DJ. Update on dengue: epidemiology, virus evolution, antiviral drugs, and vaccine development. Curr Infect Dis Rep. 2010;12(3):157-164.

8. Reiter P. Climate change and mosquito-borne disease. Environ Health Perspect. 2001;109 Suppl 1:141-161.

9. Earnest A, Tan SB, Wilder-Smith A. Meteorological factors and El Niño Southern Oscillation are independently associated with dengue infections. Epidemiol Infect. 2012;140(7):1244-1251.

10. Wilder-Smith A, Renhorn KE, Tissera H, et al. DengueTools: innovative tools and strategies for the surveillance and control of dengue. Glob Health Action. 2012;5.
Clinical Epidemiology

\section{Publish your work in this journal}

Clinical Epidemiology is an international, peer-reviewed, open access journal focusing on disease and drug epidemiology, identification of risk factors and screening procedures to develop optimal preventative initiatives and programs. Specific topics include: diagnosis, prognosis, treatment, screening, prevention, risk factor modification, systematic

\section{Dovepress}

reviews, risk \& safety of medical interventions, epidemiology \& biostatical methods, evaluation of guidelines, translational medicine, health policies \& economic evaluations. The manuscript management system is completely online and includes a very quick and fair peer-review system, which is all easy to use. 